\title{
The diversity of latent TB
}

\author{
Douglas Young \\ From Immunodiagnosis of Tuberculosis: New Questions, New Tools \\ Virginia, VA, USA. 21-23 September 2008
}

During the second half of the twentieth century, researchers have been focused on breaking down science into small pieces, and in doing so have learned that understanding the small pieces does not necessarily translate into a greater understanding of the whole. Systems biology has emerged as a way of understanding these systems in total, but requires scientists to work through complexity to arrive at a greater understanding. To understand the fundamental biology of TB, scientists must first understand the biology of latent TB: why the bacteria are able to resist the host's ability to eradicate them over a long period of time. The commonly-used definition of latent TB-antigen-specific T-cell response without clinical symptoms-is very broad and may in fact lead us away from the consideration that latent TB may not be the same in every patient. Does everyone infected with latent TB harbor viable bacteria? Where are these bacteria in the body and what are they doing?

As part of the Grand Challenges in Global Health Program, a Gates Foundation-funded initiative to develop drugs for latent $\mathrm{TB}$, our team is working with a hypoxia model, based on the idea that the bacteria encounters an environment (hypoxia) in the host which is hostile. In response, the bacteria may switch to a slowly-replicating persistent phenotype that makes them more drug-tolerant. We are also using live-imaging to study lesions in active latent TB in both humans and primates to identify what the bacteria are doing in different types of lesions, why some bacteria are immunologically active and others dormant.

Based on our findings to date, biomarkers in addition to T-cell response must be identified in order to develop a better understanding of what is happening in patients with latent TB. We hypothesize that latent TB encompasses a broad spectrum of responses in patients, from

Correspondence: d.young@imperial.ac.uk Department of Microbiology, Imperial College of London, London SW7 2AZ, UK the infection being eliminated without priming antigenspecific $\mathrm{T}$ cells, through the infection being controlled with some bacteria persisting but reduced replication, to some bacterial replication being maintained at a subclinical immune response. Our theory is that the infection in patients with latent TB can move along this spectrum over the course of time. With additional biomarkerssuch as ones measuring bacterial load or cell surface markers-subsets of patients can be identified who would benefit from preventive therapy, making this a more realistic and effective approach in the goal of eliminating TB by 2050 .

Published: 17 December 2010

doi:10.1186/1753-6561-4-S3-O2

Cite this article as: Young: The diversity of latent TB. BMC Proceedings 2010 4(Suppl 3):O2.

Submit your next manuscript to BioMed Central and take full advantage of:

- Convenient online submission

- Thorough peer review

- No space constraints or color figure charges

- Immediate publication on acceptance

- Inclusion in PubMed, CAS, Scopus and Google Scholar

- Research which is freely available for redistribution
Ciomed Central 